\title{
OIL ENGINES FOR TEXTILE MILLS
}

\section{Frank Carter}

To cite this article: Frank Carter (1912) OIL ENGINES FOR TEXTILE MILLS, Journal of the Textile Institute Proceedings and Abstracts, 3:2, 360-371, DOI: 10.1080/00405001208631734

To link to this article: http://dx.doi.org/10.1080/00405001208631734

$$
\text { 曲 Published online: } 01 \text { Dec } 2008 .
$$

Submit your article to this journal

Џll Article views: 6

Q View related articles ¿ 


\section{OIL ENGINES FOR TEXTILE MILLS.}

\section{By Frank Carter.}

BEFORE dealing specifically with the suitability of the Diesel engine for textile mill driving, it may be advisable to briefly outline the history of this engine, as, in view of the great prominence recently given to this prime mover in the technical and daily Press, the author finds there is a tendency to look upon the engine as a recent invention.

It has always been recognised by engineers and scientists that the heat efficiency, i.e., the percentage of the total heat value of the fuel converted into useful work, of most power plants is very low, and constant efforts have been made to improve this efficiency.

Dr. Diesel, a German scientist, after many years of careful experiment with different types of heat engines, came to the conclusion that comparatively little improvement could be effected unless the principles of working were considerably modified.

In I893 Dr. Diesel decided to construct an engine with the object of demonstrating his theories. The engine was constructed without water jacket, and coal dust was used as fuel, the temperature for the combustion of the fuel being obtained by compressing air only to a high pressure in the cylinder before injecting the fuel. Considerable mechanical difficulties were experienced, owing to the high pressure and resultant temperature produced. Difficulties were also experienced by ash and grit remaining in the cylinder. The experiments were continued with a water-jacketed cylinder until a solution was reached in $1895-6$ by using oil as the fuel and a compression pressure of about $460 \mathrm{lbs}$. per square inch. The fuel consumption attained with this engine was a little over $\frac{1}{2} \mathrm{lb}$. per B.H.P. hour.

Since this date the progress has been fairly rapid, and the Diesel engine using crude or residual oil has for many years been an assured success.

The cycle of operation is as follows: ist, the outward or suction stroke of the piston draws air into the cylinder from the atmosphere; 2nd, the return or inward stroke compresses this air to a pressure of about 470 lbs. per square inch, and at $\frac{1}{4}$ per cent before the completion of this stroke the fuel admission valve opens, and fuel oil is injected into the cylinder by means of compressed air provided by a direct-driven air compressor. The temperature of the air in the cylinder due to the compression of the second stroke of the piston is about I, 00o deg. Fah., and the fuel oil, entering the cylinder in a very finely-divided spray, immediately commences to 
burn. The admission of oil continues for about io per cent of the third stroke of the piston, when the engine is working at full load. The fuel supply is then cut off, expansion of the gases taking place for the remainder of the stroke. The fourth stroke of the piston is the exhaust or scavenging stroke, during which the burnt gases are completely swept out of the cylinder. The quantity of fuel admitted is controlled by the governor acting on the suction valve of the pump which delivers the fuel to the cylinder.

The method of control is as follows: The plunger of the fuel

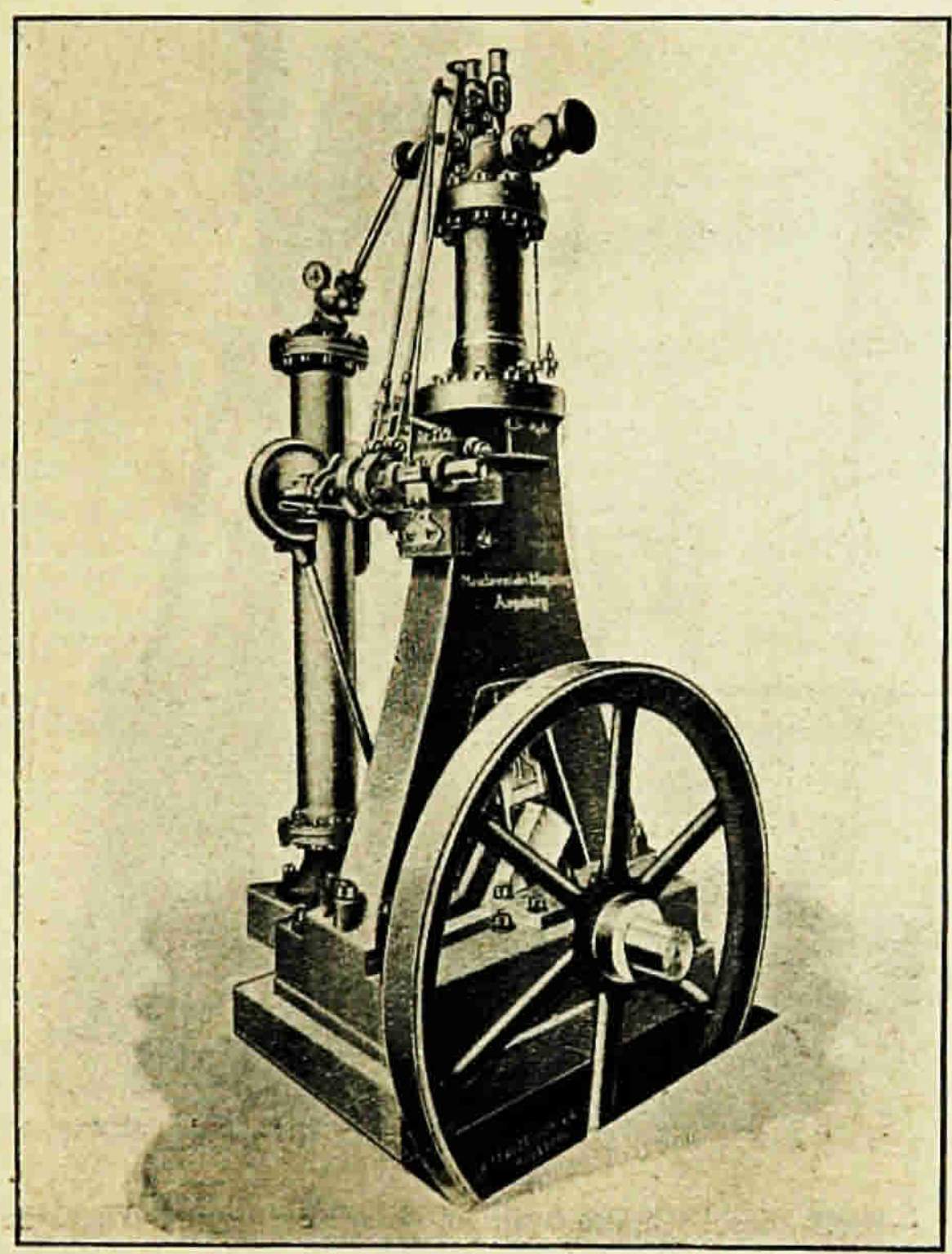

FIG. I.-First Engine built for Dr. Diesel by the M.A.N. Co. in 1893 .

pump has a displacement equal to the quantity of fuel required when working at full load, and under such condition of load the suction valve of the pump closes immediately the delivery stroke of the plunger commences, and delivers the full quantity of fuel to the cylinder. If, however, the engine is working at half load, the governor holds the suction valve open for half the delivery stroke of the pump, allowing about half the fuel oil to 
return to the suction chamber; the suction valve then closes, and the remainder of the oil is delivered. Consequently the amount of fuel supplied to the engine varies with the load.

For example, an engine of 320 B.H.P. would consume about I $40 \mathrm{lbs}$. of fuel oil per hour at full load, and about $\mathrm{S}_{4}$ lbs. at half load.

It is the practice of the firm with whom the author is associated to fit a separate pump for each cylinder of multi-cylinder engines, thus ensuring an equal distribution of the fuel.

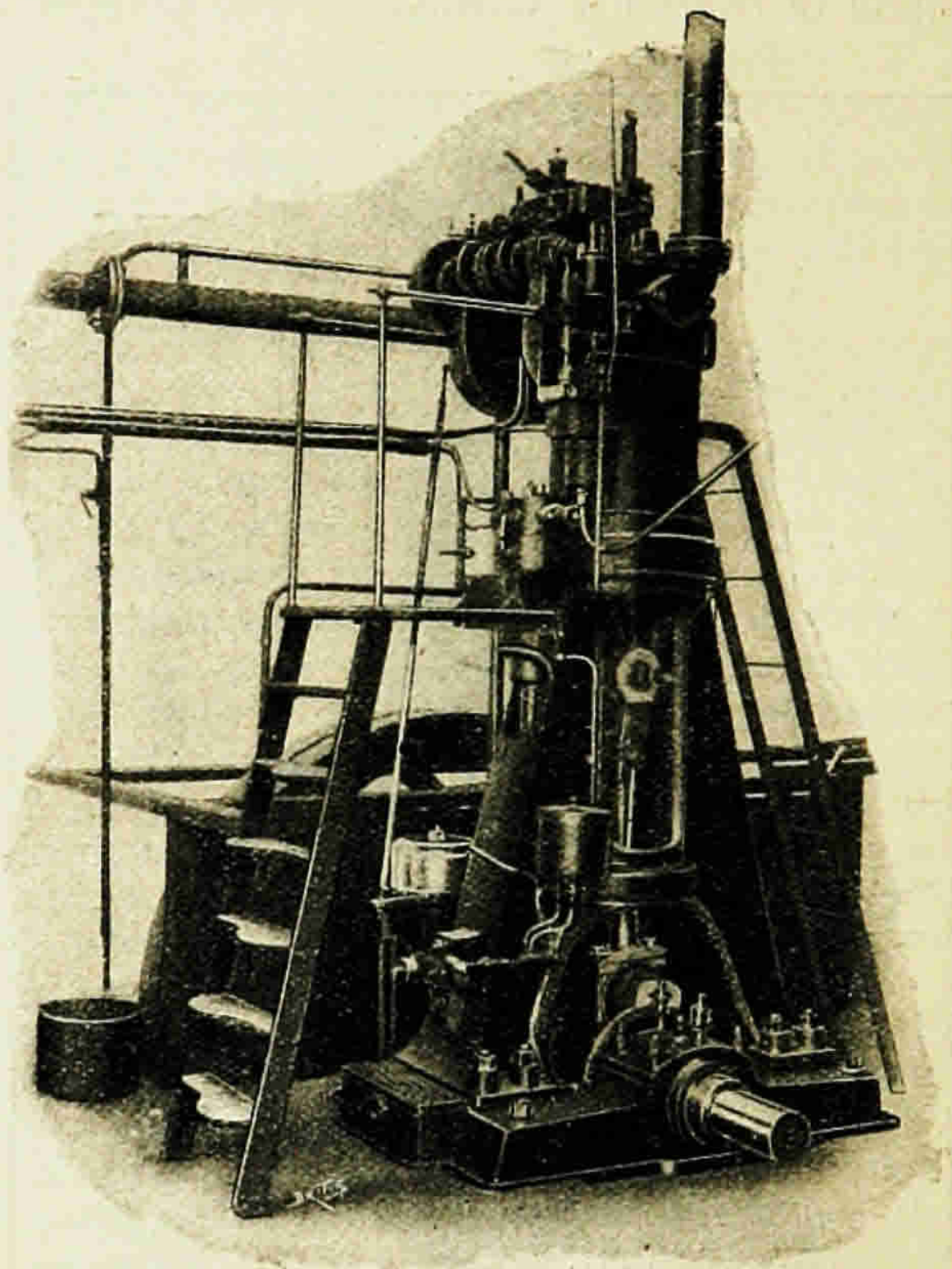

FIG. 2.-First Diesel Fingine built in Great Britain by The Mirrlees Watson Co. Ltd., Glasgow, in 1896.

In dealing with the application of the Diesel engine to textile mill driving it is obviously impossible to do more within the time at the author's disposal than indicate the general lines on which the engine could be utilised. Conditions vary, and each case, to be strictly accurate, would require to be dealt with on its merits.

The figures given in the following tables have been carefully compiled from data available from installations in daily service. Allowance has been made in the tables for the provision of steam for heating and manufacturing processes, the figures covering this having hoen obtained from actual costs both as regards capital and 
fuel. The author is of opinion that considerable economy in the fuel cost for the provision of the steam could be effected by the use of the exhaust gases from the engine for feed water heating, and the use of oil fuel in place of coal or coke for firing the boiler.

It is proposed to take as examples a weaving shed of average size, requiring an engine of 320 B.H.P., and a spinning mill requiring an engine $\mathrm{I}, 000$ B.H.P. The cost of fuel oil is taken at 5 os. per ton, and this figure would cover cost of delivery into user's tank. One engineer would be required in the case of

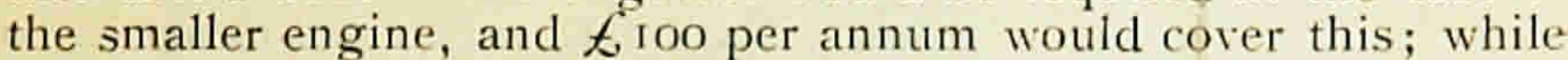
in the case of the larger engine an assistant might be considered necessary, and an additional $£ 65$ per annum is included for this assistant.

The following tables give the costs for both sizes of engine:-

\section{B.H.P. DIESEL ENGINE.}

Capital Cost for Rope Transmission.

Cost of engine, friction clutch and rope pulley......

Oil storage tank, with pump and piping ...........

Low-pressure steam boiler, with I, $400 \mathrm{ft}$. of 2 in. steam piping, chinney, and fixing complete....

Buildings and foundations.....................

Capital Charges will be as under:-

\begin{tabular}{rrr}
$f$ & s. & $d$ \\
2,870 & 0 & 0 \\
60 & 0 & 0 \\
135 & 0 & 0 \\
500 & 0 & 0 \\
\hline$£ 3,565$ & 0 & 0 \\
$£$ & s. & d. \\
287 & 0 & 0 \\
I9 & I0 & 0 \\
40 & 0 & 0 \\
\hline$£ 346$ & I0 & 0
\end{tabular}

Running costs, allowing 2,750 working hours per annum, and taking the average load as 240 B.H.P., which allows for a portion of the machines standing idle while adjustments or changes are being made:-

Fuel oil, I 42 tons at 50 s.

f. s. d.

Lubricating oil, waste, water and stores ............

Repairs and maintenance $\ldots \ldots \ldots \ldots \ldots \ldots . . . . .$.

Coke for heating (I ton per week) at I $35 . . . . . . . .$.

Wages....................................

355 o 0

$\begin{array}{lll}39 & 0 & 0\end{array}$

$\begin{array}{lll}40 & 0 & 0\end{array}$

32 Io 0

IOO 00

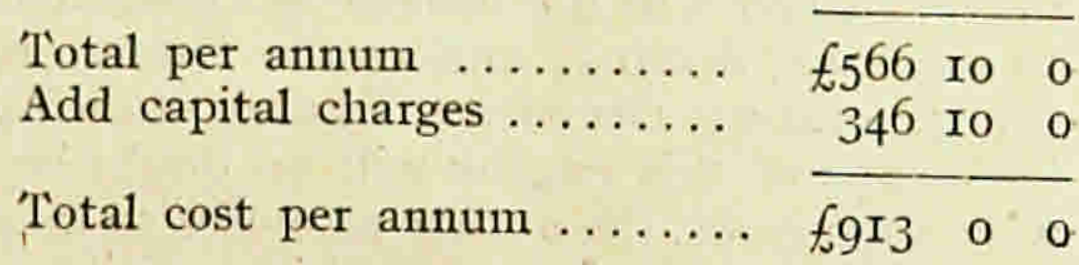

Or a total cost inclusive of capital charges of 0.33 pence per B.H.P. per hour. 


\section{I,000 B.H.P. DIESEL ENGINE.}

Capital Cost for Rope Transmission.

Cost of engine, friction clutch and rope pulley...... $8,750 \quad 000$

Oil storage tank, pump and piping $\ldots \ldots \ldots \ldots \ldots$. 90 . 0 . 0

Boiler, piping, and feed pump for heating ....... $250 \quad 0 \quad 0$

Buildings and foundations................. I,200 0

Capital Charges will be:-

Total......... £ ro,290 o

Interest and depreciation on engine, \&c., at ro per cent. 875 o 0 ". boiler, tank, \&c., $\quad 34$ buildings and foundations $\quad 340$ at 8 per cent $\ldots \ldots . \quad 96 \quad 0 \quad 0$

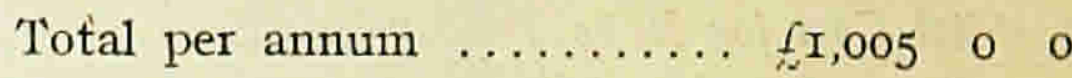

Rumning costs, allowing an average load of 90 per cent of full load, viz :-900 B.H.P.

$f \quad$ s. d.

Fuel oil, 495 tons at 50 . $\ldots \ldots \ldots \ldots \ldots \ldots \ldots \ldots$ I,237 Io o

Lubricating oil, waste, water and stores ........ Iog Io 0

Coal for heating purposes, I50 tons at IIs. ...... 82 Io 0

Repairs and maintenance ............... Ioo 0 o

Wages....................... I6 $6_{5} 0$

Total per annum ........ f $f, 694$ Io 0

Add capital charges ........ I,005 0 .

Total cost per annum ...... £2,699 Io 0

Or a total cost inclusive of capital charges of 0.26 pence per B.H.P. per hour.

In calculating fuel costs the guaranteed fuel consumption for the sizes of engines specified has been taken as the basis, while in the items for lubricating oil, waste water, stores, repairs and maintenance actual figures from plants in daily service have been taken.

The above figures relate to the driving of textile factories by means of ropes in the usual way, but, in view of the interest taken in electrical driving, and as the Diesel engine is extensively used for generating electricity, figures showing the cost of generating by means of this engine will no doubt be of interest. In dealing with such costs, the author proposes to take exactly the same conditions, so that the figures will be readily comparable, but does not propose to take into account the provision of steam for heating and manufacturing processes, as the cost of this would be the same 
whether the power were purchased from a public supply or generated on the premises. Also it is intended to deal with the generating plant only, leaving the distribution of electric power to the author of the paper on electrical driving. In the case of the spinning mill it is proposed to divide the power into two units of 500 B.H.P. each instead of one unit of $\mathrm{r}, \mathrm{OOO}$ B.H.P. This will

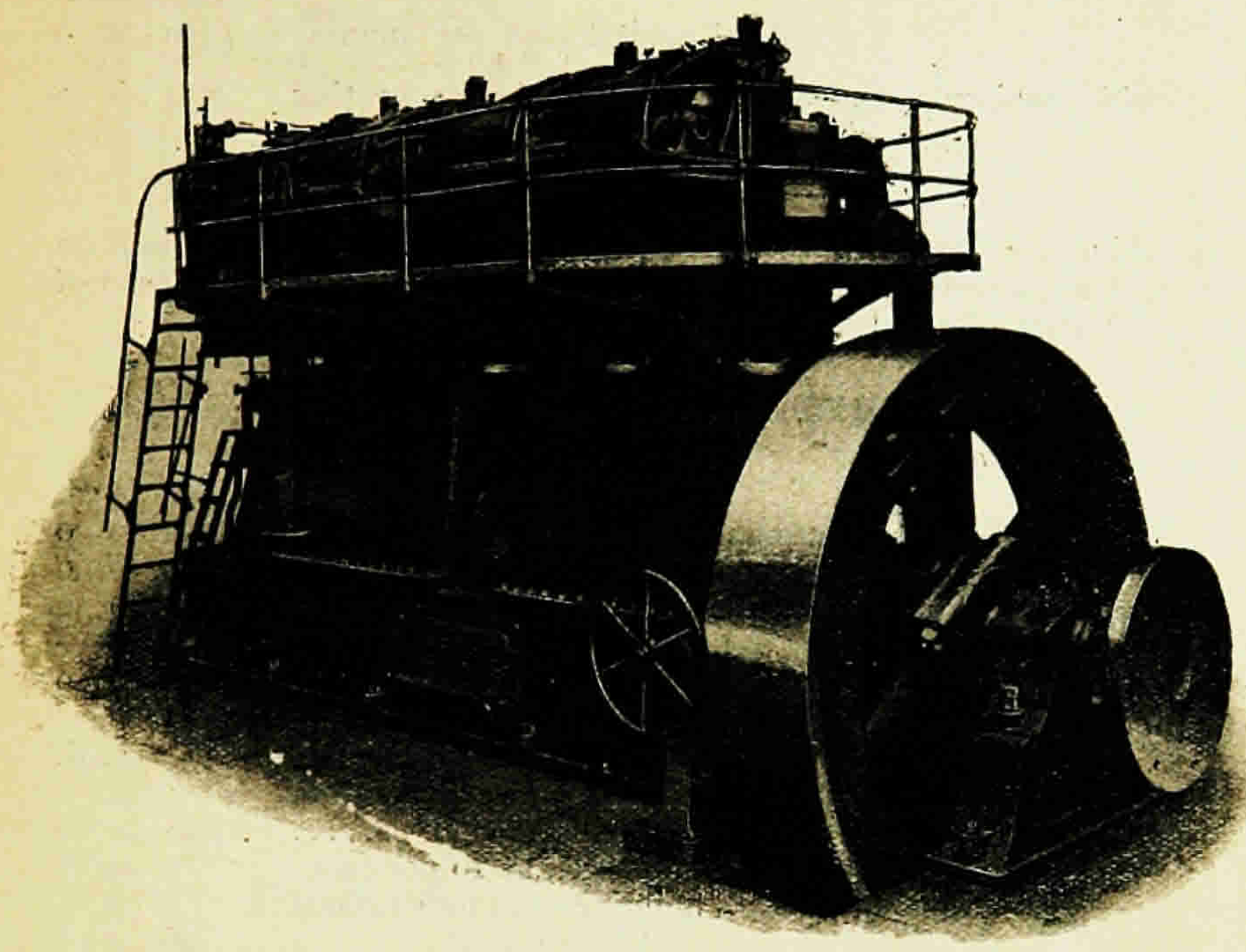

FIG. 3. -5 oo B.H.P. Diesel Engine, by Mirrlees, Bickerton \& Day Ltd., Stockport.

increase the capital cost somewhat, but the compensating advantages would counterbalance this, while the running costs would be the same.

320 B.H.P. DIESEL ENGINE WITH ALTERNATOR.

Capital Costs :-

Engine and alternator complete $f$ s. d.

Oil storage tank, with pump and p..............

Buildings and foundations

\begin{tabular}{rrr}
$£$ & s. & d. \\
3,244 & 0 & 0 \\
60 & 0 & 0 \\
500 & 0 & 0 \\
\hline 3,804 & 0 & 0
\end{tabular}




\section{Capital Charges :-}

Interest and depreciation on engine and alternator at Io per cent $\ldots \ldots \ldots \ldots \ldots \ldots \ldots \ldots \ldots \ldots \ldots \ldots$.

Interest and depreciation on tank, \&c., at io per cent.. , , buildings and foundations at 8 per cent.........

Total capital cost per annum

Add running costs as before, except coke for heating

Total cost per annum ........

$£ \quad$ s. d.

32480

$40 \quad 0 \quad 0$

$£ 370 \quad 8 \quad 0$

$534 \quad 0 \quad 0$

$£ 904 \quad 8 \quad 0$

Taking the generator efficiency as 92 per cent at full load, and 90 per cent at three-quarter load, the cost per unit with an average load of three-quarters of full load would be 0.49 pence.

Two 500 B.H.P. DIESEL ENGINES, WITH ALTERNATORS. Capital Costs :-

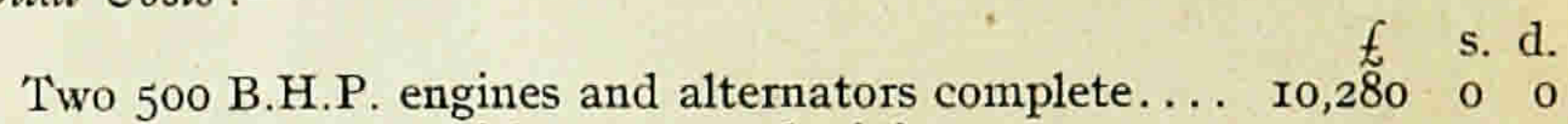

Oil storage tank, with pamp and piping ......... $90 \quad 0 \quad 0$

Buildings and foundations.................. I,200 $\quad 0 \quad 0$

Total. $f I I, 570 \quad 0 \quad 0$

Capital Charges :-

$£$ s. d.

Interest and depreciation on engines and alternators at Io per cent ....... I, 028 o 0 $\begin{array}{ll}\text { ", } & \text { tank, \&c., at ro per cent. } \\ \text { ", } & \text { buildings and foundations }\end{array}$ 900 at 8 per cent .........

$96 \quad 0 \quad 0$

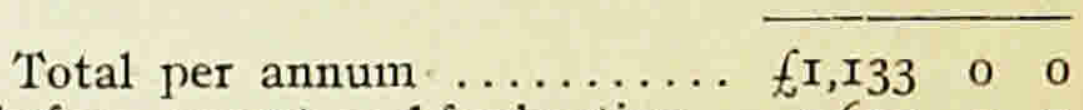
Add running costs as before, except coal for heating. . I,6I2 $0 \quad 0$

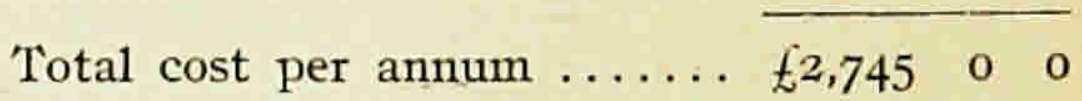

Taking the efficiency of the generator as 92 per cent at full load, and allowing an average load of 900 B.H.P., the total cost per unit would be 0.39 pence.

In comparing various types of power plant it is not sufficient to consider the amount of fuel used by the prime mover only. Allowance must be made for all auxiliaries such as economisers, boiler feed pumps, condensing plant, cost of water for condensing purposes, and stand-by losses in the case of steam plant. Also in comparing the cost of repairs and maintenance, the auxiliaries must be taken into account, as the repairs on these will probably amount to a sum considerably in excess of the repairs to the engine only, and, of course, the steam plant is not complete without such 


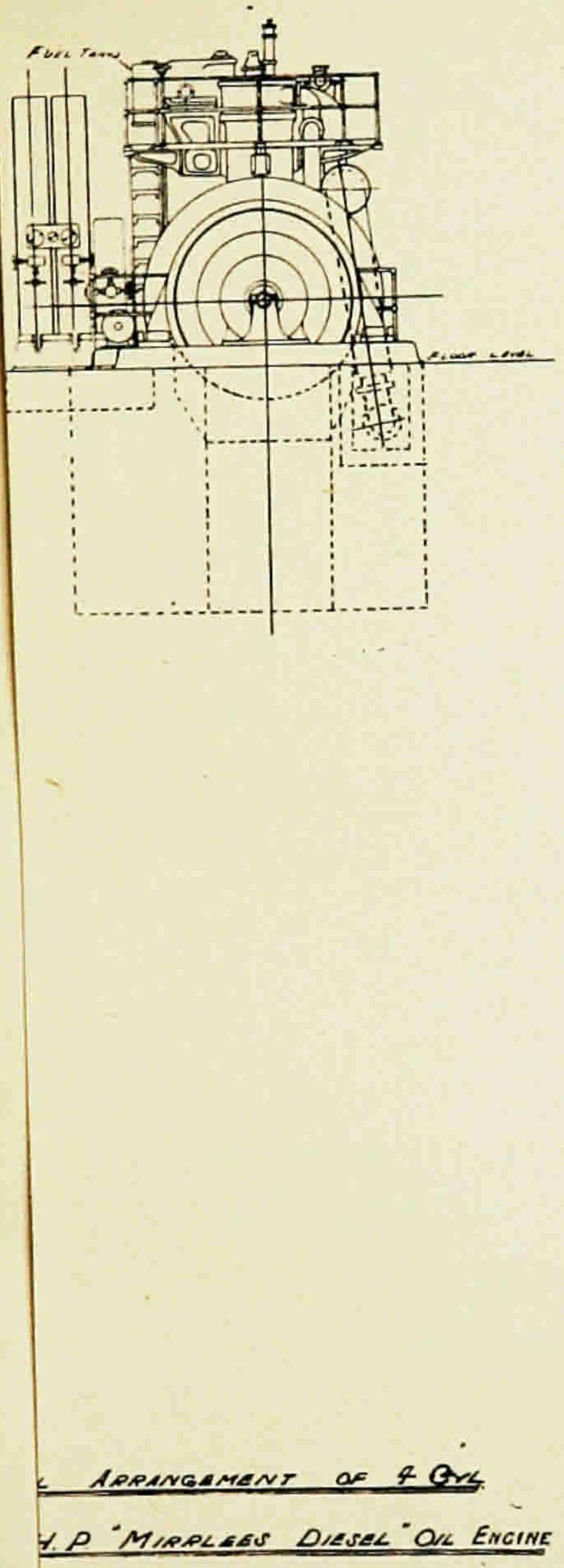

- ConpLEP TO. ALTEPNATOB 

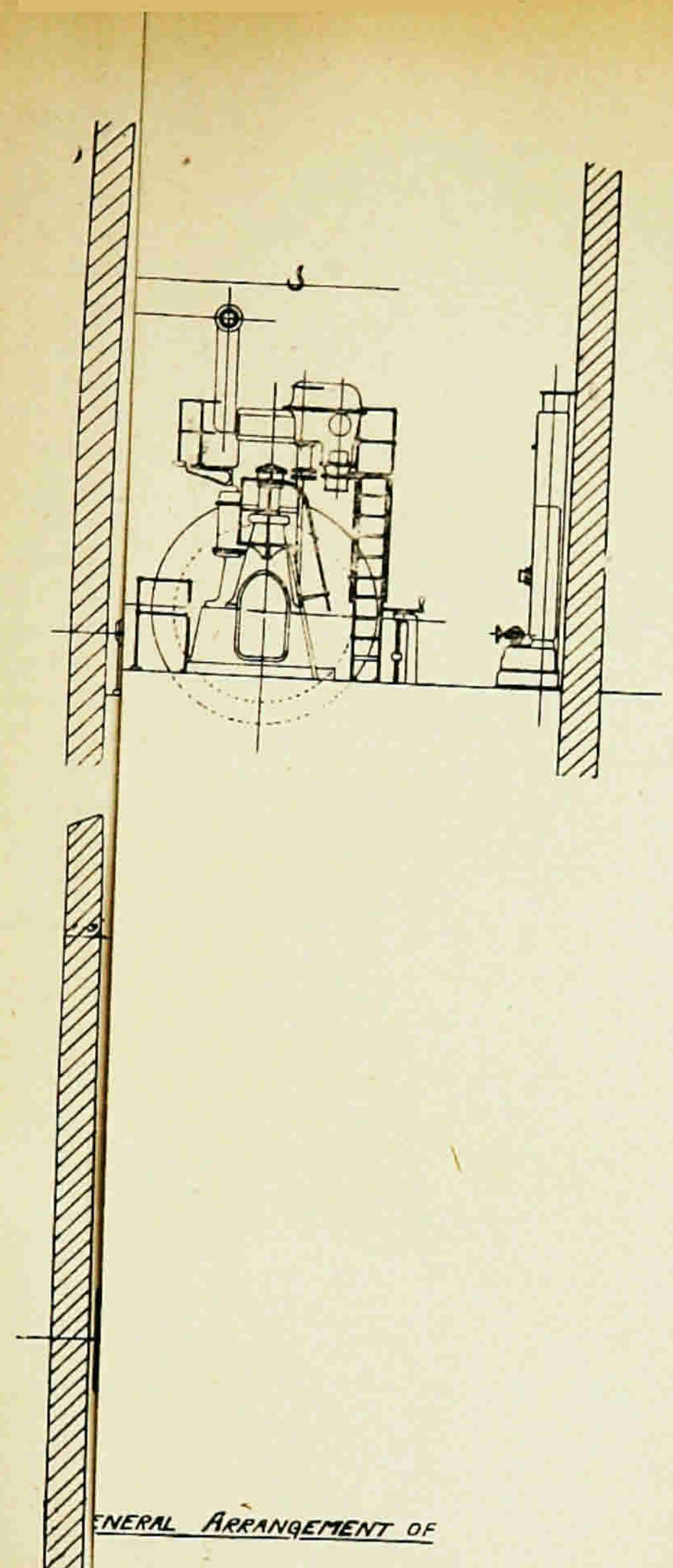

RLEES - DIESEL" OIL ENGINE

ie Throvad Filction Cluteh

REW PEP MIN 
auxiliaries. An allowance should also be made for cost of cleaning boilers, economisers, and flues. Similarly with gas plant, the stand-by losses and cost of water for scrubbers or gas cleaning and cooling plant must be taken into account. Also repairs and maintenance on both gas plant and engine. Under local by-laws, it is often compulsory that the effluent from the gas cleaning plant should be filtered and deodorised before turning it into drains or waterways to prevent pollution.

The figures given above and those given in the other papers will enable a comparison to be made as to the wages cost for the three types of plant.

It should be noted that the Diesel engine is a self-contained power plant, and no auxiliaries requiring attention by stokers or other labour are required to enable the engine to drive the productive machinery, consequently the number of men engaged in the running of the plant can be reduced to a minimum.

Another matter which appears to the author to be worthy of consideration is the amount of space required for storage of the different kinds of fuel. For instance, a $30 \mathrm{ft}$. by $8 \mathrm{ft}$. 6 in. boiler shell would hold about 30 tons of oil, sufficient fuel to run the larger plant referred to above at full load for about three weeks.

The handling of this oil is a simple matter, as it can be drained from the tank wagon into the storage tank by gravity or, at the worst, emptying the tank wagon by means of a pump, whereas the handling of coal or coke sufficient to run a steam or gas plant for the same period would be a different problem, remembering also that there is a fair amount of wastage in handling coal. Again, the disposal of ashes and clinkers in both gas and steam plant is often a difficult matter, especially in congested areas, and the author knows of more than one case where this problem has forced manufacturers to look round for some other source of power. It should also be noted that with the Diesel engine, working under proper conditions, there is no trouble from the emission of smoke or noxious fumes.

Two points which are of great importance to textile manufacturers are steady turning and reliability. As regards the former, the Diesel engine can be guaranteed to give quite as good results as the most modern steam engine, whilst as regards the latter the firm with whom the author is associated installed an engine at Birkdale some five vears ago which has averaged $23 \frac{1}{2}$ hours out of every 24 hours during this period, and is regularly run for five and six weeks without a stop. This engine underwent its first overhaul last summer, after four years' service under these conditions, and the cost of new parts, consisting of piston rings, springs, and small parts of similar character, amounted to $E^{24}$. There is no reason why a Diesel engine, receiving a reasonable amount of care and attention, should be more expensive in maintenance, proportionately, of course, to size, than this, and it is distinctly the author's experience that where a Diesel engine receives such reasonable care the cost of repairs is very low. 
The question is often raised as to whether the supply of fuel oil is sufficient to meet the demand in view of the rapidly increasing use of the Diesel engine for power purposes. The map may assist to dispel any fears in this respect. The black dots show the oil fields being worked at the present time. New fields are continually being opened up, whilst the capacity of the existing fields is not yet fully developed.

Recent enquiries show that the price of oil at the oil fields has not varied appreciably during the last io years. The reason given for the fluctuation in prices to users is that such fluctuation is due to the fact that the number of oil-carrying vessels is inadequate to meet the demand, particularly in view of the greatly increased consumption of petrol and the lighter oils. To remedy this shortage, 66 large oil-carrying vessels have

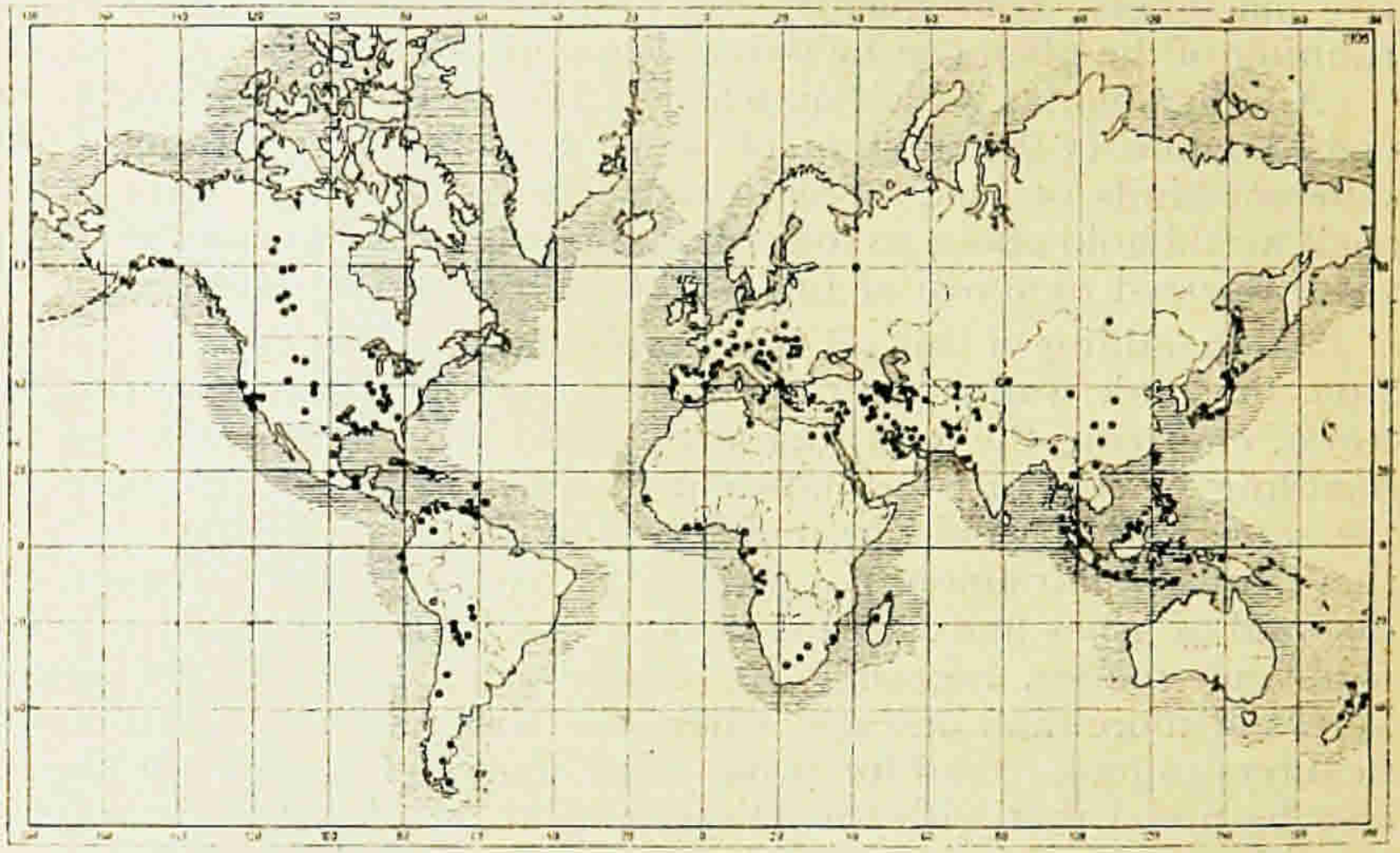

FIG. 3A.-Map showing World's Oil Fields.

recently been ordered, some of which are expected to be in service in a few weeks. The author was recently assured by the general manager of one of the largest oil-supplying companies that as soon as these were in service the price of fuel oil would revert to normal. Recent experiments have proved that in addition to the cheap residual oils, the Diesel engine can successfully use oil distilled from tar, and a number of installations using such oil are at work.

The main advantages of the Diesel engine may be summarised as follows:-

i. Its economy in fuel consumption and entire absence of stand-by losses.

2. The fuel used is safe, cheap, and the storage of same occupies little space, enabling users in case of necessity to meet such an event as, say, a transport strike, without inconvenience and without the risk of the fuel deteriorating in heat value due to exposure. The flash point of the oil is about $200 \mathrm{deg}$. Fah., consequently there is no risk from fire or spontaneous combustion. 
3. The freedom of the engine from pre-ignition or, as it is commonly expressed, back-firing. The reason for such freedom being that air only is compressed, and not a mixture of air and oil or air and gas. This fact eliminates one of the most frequent causes of breakdown in other internal-combustion engines.

4. The absence of vaporisers, carburetters, and ignition devices. These in other forms of internal-combustion engines are frequently a source of trouble.

5. The engine can easily be started up, $1 \frac{1}{2}$ to 2 minutes being sufficient to get the engine on full load. There is no warming up or other preparation, the engine being started on compressed air.

6. Being self-contained, it is compact, and the absence of noise, vibration, smell, smoke, or fire risks makes the engine eminently suitable for use in congested areas and business premises.

In conclusion, it may be of interest to note that a considerable number of Diesel engines have been installed in textile factories, particularly in India, as the following list shows:-

Name.

Size.

Method of driving.

Bombay Cotton Manufacturing Co. Ld. One 400 B.H.P.. Ropes.

Crown Mill, Bombay ........... One 250

Poona Cotton and Silk Co. Ltd. ... One I6o

Poona Swadeshi Mills ............ One 80

Kohinoor Mills, Bombay ........ One 400

Khatau Makanji S. \& W. Co. ..... One 500

Maneckji Petit Mills, Bombay ..... One 375

Gomtipur Sp. Co. Ltd., Ahmedabad. . One 250

Buckingham Mills Co. Ltd., Madras... One 240

Khatau Makanji Ginning Co. ...... Two I60

Chaturbhooj Doorgadas Ginning and One I60

Pressing Co.

Finlay Mills, Bombay........... Three 400

E. D. Sassoon Mill, Bombay ...... Two 400

Jacob Sassoon Mill, Bombay ....... Two 525

Kaleeswarar Mills, Coimbatore ..... One 525

W. \&. J. Knox Ltd., Kilbirnie .... One 40

Robinson \& Co., Greenfield ........ One I60

S. Heap \& Sons Ltd., Rochdale ..... One 80

National Cotton Spinning Co., Bulgaria One 200

Athlone Woollen Mills Ltd. ....... One 250

The author is aware that there are Diesel engines driving textile mills in other parts of India, but those mentioned above came under his personal supervision, and it is interesting to note that two at least of the installations are about to be extended, replacing the existing steam engines. It may be said that the price of coal in India is favourable to the installation of Diesel engines, but the author's experience is that the relative price of coal and fuel oil is practically the same as in this country. With the exception of the electrically-driven installations, the Diesel engines in India are run by native labour, which is certainly not the most efficient in the world. 


\section{Appendix.}

The following tables are abstracted from the figures published by the "Electrical Times," and while the figures would not be applicable to an ordinary works or mill power plant, as they include charges for cable maintenance and other items incidental to a public power supply station, they give an authoritative and independent comparison of running costs of the different types of plant :-

TABLE I.-AVERAge COST PER B.T.U. Sold.

\begin{tabular}{|c|c|c|c|c|c|c|}
\hline $\begin{array}{c}\text { Type of } \\
\text { Engine. }\end{array}$ & Fuel. & $\begin{array}{c}\text { Lubricating } \\
\text { Oil, Waste, } \\
\text { Stores, and } \\
\text { Water. }\end{array}$ & Wages. & $\begin{array}{c}\text { Repairs } \\
\text { and } \\
\text { Main- } \\
\text { tenance. }\end{array}$ & $\begin{array}{c}\text { Total } \\
\text { Works } \\
\text { Cost. }\end{array}$ & $\begin{array}{c}\text { Load } \\
\text { Factor. }\end{array}$ \\
\hline Stea11 .... & 0.45 & 0.06 & 0.25 & 0.26 & 1.02 & 147 \\
Gas ...... & 0.43 & 0.09 & 0.28 & 0.24 & 1.04 & 15.3 \\
Diesel .... & 0.23 & 0.04 & 0.19 & 0.07 & 0.53 & 14.3 \\
\hline
\end{tabular}

TABLE II.-Average Works CosT PER B.T.U. SOI,D, oN Steam Stations of DIFFERENT SIZES.

\begin{tabular}{|c|c|c|c|c|c|c|}
\hline $\begin{array}{l}\text { Capacity } \\
\text { Station } \\
\text { not Ex- } \\
\text { ceeding }\end{array}$ & Fuel. & $\begin{array}{c}\text { Lubricating } \\
\text { Oil, Waste, } \\
\text { Water, and } \\
\text { Stores. }\end{array}$ & Wages & $\begin{array}{l}\text { Repairs } \\
\text { \& Main- } \\
\text { tenance. }\end{array}$ & Total. & $\begin{array}{l}\text { Load } \\
\text { Factor. }\end{array}$ \\
\hline $250 \mathrm{kw}$. & 0.63 & 0.09 & 0.35 & 0.36 & I. 43 & 13.2 \\
\hline 500, & 0.56 & 0.06 & 0.27 & $0: 29$ & $I \cdot I 8$ & $13 \cdot 3$ \\
\hline $75^{\circ}$, & 0.43 & 0.05 & 0.23 & 0.24 & 0.95 & 154 \\
\hline $1,000,$, & 0.40 & 0.05 & 0.23 & 0.21 & 0.89 & 16.8 \\
\hline $\mathrm{I}, 500$, & 0.42 & 0.04 & O.I 7 & 0.18 & $0.8 I$ & 16.9 \\
\hline 2,000 ," & $0 \cdot 37$ & 0.04 & 0.16 & 0.21 & $0.7^{8}$ & $17 \% 7$ \\
\hline 3,000 ," & $0 \cdot 33$ & 0.04 & 0.15 & 0.17 & 0.69 & 174 \\
\hline 4,000, & 0.40 & 0.03 & 0.14 & 0.20 & 0.77 & 18.8 \\
\hline 5.000, & 0.34 & 0.03 & 0.11 & 0.16 & 0.64 & 18.7 \\
\hline 7,000, & 0.36 & 0.04 & 0.13 & 0.20 & $0 \cdot 73$ & $17 \cdot 9$ \\
\hline 10,000, & 0.26 & 0.03 & 0.09 & 0.13 & 0.51 & $22 \cdot 6$ \\
\hline 20,000, & 0.30 & 0.03 & O.II & 0.16 & 0.60 & $19^{\circ} 6$ \\
\hline $5^{\circ}, 000$, & $0: 23$ & 0.02 & O'I0 & O:II & 0.46 & $20 \cdot{ }_{5}^{6}$ \\
\hline
\end{tabular}


Vol. III., No. 2.] OIL ENgines for Textile Mirlis.

It should be noted that in Table I. stations of a capacity not exceeding I,000 H.P. have been taken, the reason for this limit being that as yet there are no large electricity supply stations equipped solely with Diesel engines or gas engines.

Attention may be drawn to the figures in Table II., from which it will be noted that the economy of the Diesel engine is reached only by the largest steam stations. 